\title{
Evaluation of the new ADA and WHO criteria for classification of diabetes mellitus in young adult people (15-34 yrs) in the Diabetes Incidence Study in Sweden (DISS)
}

\author{
H. Borg ${ }^{1,8}$, H. J. Arnqvist ${ }^{2}$, E. Björk ${ }^{3}$, J. Bolinder ${ }^{4}$, J. W. Eriksson ${ }^{5}$, L. Nyström ${ }^{6}$, J-O. Jeppsson ${ }^{7}$, G. Sundkvist ${ }^{1}$ \\ ${ }^{1}$ Department of Endocrinology, Malmö University Hospital, Malmö, Sweden \\ ${ }^{2}$ Department of Internal Medicine, Faculty of Health Science, Linköping, Sweden \\ ${ }^{3}$ Department of Medicine, University Hospital, Uppsala, Sweden \\ ${ }^{4}$ Department of Internal Medicine, Huddinge Hospital, Huddinge, Sweden \\ ${ }^{5}$ Department of Medicine, University hospital, Umeå, Sweden \\ ${ }^{6}$ Epidemiology Department of Public Health and Clinical Medicine, Umeå University, Umeå, Sweden \\ ${ }^{7}$ Department of Clinical Chemistry, Malmö University Hospital, Malmö, Sweden \\ 8 Wallenberg Laboratory, Malmö University Hospital, Malmö, Sweden
}

\begin{abstract}
Aims/hypothesis. We aimed to evaluate how an aetiology-based classification, as recommended in the ADA and WHO guidelines for classification of diabetes mellitus, matches clinical judgement in the Diabetes Incidence Study in Sweden (DISS), a study covering incident cases of diabetic patients aged 15 to 34 years.

Methods. During a 1-year period (1998), blood samples were taken at diagnosis and 4 months (median) thereafter. Patients were classified according to clinical judgement by the reporting physicians and assessments of islet antibodies (ICA, GADA, and IA-2A) and plasma C-peptide.

Results. In 1998, 422 patients were registered in DISS. Among the 313 patients participating in the follow-up, most with clinical Type 1 diabetes $(185 / 218,85 \%, 95 \%$ CI $79-89 \%)$ were islet antibody positive $(\mathrm{ab}+)$ at diagnosis. In addition, 14 out of 58 (24\%, 14-37\%) with clinical Type 2 diabetes and 21 out of $37(57 \%, 40-73 \%)$ with unclassifiable diabetes were antibody positive at diagnosis. Further to this, 4 out of $33(12 \%, 3-28 \%)$ were antibody negative with
\end{abstract}

clinical Type 1 diabetes and 4 out of 44 (9\%, 3-22\%) with Type 2 had converted to antibody positive at follow-up. Among those who were constantly antibody negative, 10 out of $29(34 \%, 18-54 \%)$ with clinical Type 1 and 1 out of $16(6 \%, 0-30 \%)$ with unclassifiable diabetes had fasting plasma C-peptide concentrations below the normal range $(<0.25 \mathrm{nmol} / \mathrm{l})$ at follow-up.

Conclusion/interpretation. Most young adults with clinical Type 1 diabetes (199/218, 91\%) had objective Type $1(\mathrm{ab}+$ at diagnosis/follow-up and/or low fasting plasma C-peptide concentrations at follow-up), as did one third $(18 / 58,31 \%)$ with clinical Type 2 diabetes and more than half $(22 / 37,59 \%)$ with unclassifiable diabetes. About $10 \%$ of those who were antibody negative converted to antibody positive. Our study underlines that a classification considering aetiology is superior to clinical judgement. [Diabetologia (2003) 46:173-181]

Keywords Autoantibodies, BMI, C-peptide, classification, GADA, IA-2, ICA, idiopathic, Type 1 diabetes, Type 2 diabetes.
Received: 8 July 2002 / Revised: 1 October 2002

Published online: 8 February 2003

CC Springer-Verlag 2003

Corresponding author: Dr. H. Borg, Wallenberg Laboratory, Entrance 46 2nd floor, Malmö University Hospital, 20502 Malmö, Sweden.

E-mail: Henrik.Borg@endo.mas.lu.se
Abbreviations: ab+, antibody positive; ab-, antibody negative; C-peptide, connecting peptide; DASP, Diabetes Autoantibody Standardization Programs; DISS, Diabetes Incidence Study in Sweden; GADA, glutamic acid decarboxylase 65 antibodies; IA-2A, protein tyrosine phosphatase-like protein IA-2 antibodies; ICA, islet cell antibodies; JDF, Juvenile Diabetes Foundation. 
A correct classification of diabetes (Type 1 vs. Type 2) is important with regard to treatment (insulin or not) and prognosis $[1,2,3]$. Previous criteria for classification were based on a clinical assessment and the type of treatment used [4, 5, 6]. Different studies have, however, shown that these criteria have difficulties to distinguish between Type 1 diabetes and Type 2 diabetes $[7,8,9]$. Consequently, a classification based on aetiology was considered necessary [10, 11]. In 1997, the Expert Committee on the diagnosis and classification of diabetes mellitus, sponsored by the American Diabetes Association (ADA), published new criteria based on disease aetiology [12], later also included in the new WHO guidelines in 1998 [13]. Most young adults with diabetes are clinically classified as having Type 1 diabetes [14]. As in elderly patients [15, 16], a substantial proportion of young adults with islet antibodies are not considered as having Type 1 diabetes $[15,17,18]$. Islet antibodies in patients with clinical Type 2 diabetes predict future insulin treatment within 6 years $[15,19]$, and accordingly, Type 1 diabetes. In agreement with the concept of ADA and WHO, that aetiology has to be considered in the classification of diabetes, we measured islet antibodies, as markers of autoimmunity, and C-peptide, as a marker of beta-cell destruction, in incident cases of young adults, 15 to 34 years old, with newly diagnosed diabetes, registered in the nationwide Diabetes Incidence Study in Sweden (DISS) during 1998. The aim of this study was to evaluate how well a classification based on aetiology, as inferred by islet antibodies and C-peptide, corresponds to a classification based on clinical judgements in young adult diabetic patients.

\section{Material and Methods}

Subjects. Since 1983, the Diabetes Incidence Study in Sweden (DISS) aimed to register all patients aged 15 to 34 years at the diagnosis of diabetes in Sweden [14]. In 1998, 422 patients, 15 to 34 year-old, [median 25 (inter quartile range 10) years] were registered, of these $168(40 \%)$ were women. Blood samples were available from 394 of 422 patients (93\%) at registration, collected (random $=$ anytime of the day) 6 (21) days after diagnosis [within 1 week after diagnosis in 205 patients $(53 \%)$, within 2 months in 338 patients [ $(86 \%)$, and within 14 months in 388 patients $(98 \%)$ ]. A second, fasting sample was available from 313 of 422 patients (74\%), collected 109 (99) days after diagnosis [within 12 weeks after diagnosis in 53 patients (17\%), within 6 months in 192 patients $(61 \%)$ and within 12 months in 273 patients (87\%)]. The individual patient's physician gave his/her opinion of the clinical classification at diagnosis on the DISS registration form of 418 patients. Excluded from the analysis were three patients, clinically classified as having secondary diabetes. Information about origin (place of birth) of the patients was obtained from their civic numbers. The study was approved by the Ethics Committee of the Karolinska Institute and all subjects gave informed consent.

Methods. GADA and IA-2A were assessed by radioligand binding assays based on ${ }^{35} \mathrm{~S}$-methionine-labelled human re- combinant antigens $[20,21]$. The results are shown as indexes calculated according to the formula $100 \times(\mathrm{u}-\mathrm{n}) /(\mathrm{p}-\mathrm{n})$, where $\mathrm{u}=\mathrm{CPM}$ of the unknown sample, $\mathrm{n}=\mathrm{CPM}$ of a negative control, and $\mathrm{p}=\mathrm{CPM}$ of a positive control. $\mathrm{CPM}=$ mean radioactivity of the measurements. In the first Diabetes Autoantibody Standardization Programs (DASP), this GADA assay was carried out with $80 \%$ sensitivity and $96 \%$ specificity and the IA-2A assay with $58 \%$ sensitivity and $100 \%$ specificity (50 patients aged 9-30 years and 50 healthy donors aged $18-28$ years were tested). A GADA index above 4.6 and IA-2A index above 1.0 (97.5 percent of 165 non-diabetic controls aged 7-34 years), respectively, were considered abnormal [22].

ICA were assessed by a prolonged immunofluorescence assay. In the latest Diabetes Autoantibody Proficiency Program (no. 13, 20 samples were tested), this ICA assay was carried out with $100 \%$ sensitivity and $100 \%$ specificity (ICA have been excluded from the DASP). In this study the detection limit was four JDF units for the used pancreas; i.e. an ICA value of four JDF units or more was considered abnormal. Islet antibodies were measured in the 394 patients at diagnosis. Among patients without islet antibodies or with only IA-2A at diagnosis, the second, follow-up, sample was tested for all three antibodies. We have shown that the occurrence of only IA-2A is not associated with the development of beta-cell failure in adult diabetic patients; and is therefore an unreliable sign of autoimmune Type 1 diabetes in adults [22].

Plasma C-peptide (P-C-peptide) was assessed by RIA and the normal range for fasting P-C-peptide was 0.25 to $0.75 \mathrm{nmol} / \mathrm{l}$ and the detection limit $0.10 \mathrm{nmol} / \mathrm{l}$ for the assay used [23]. In this study, a P-C-peptide concentration less than $0.25 \mathrm{nmol} / \mathrm{l}$ was considered low and less than $0.10 \mathrm{nmol} / \mathrm{l}$ as beta-cell failure [22].

Blood samples for $\mathrm{HbA}_{1 \mathrm{c}}$ measurements were treated with a cysteine-reducing solution to eliminate the glutathione adduct $\left(\mathrm{HbA}_{3}\right.$ or $\left.\mathrm{HbA}_{1 \mathrm{~d}}\right)$ [24] after storage at $-20^{\circ} \mathrm{C}$ for 1 to 2 years. $\mathrm{HbA}_{1 \mathrm{c}}$ was assessed by HPLC using Mono $\mathrm{S}$ ion exchange chromatography (Pharmacia-Amersham Bioscience, Uppsala, Sweden) [25]. The reference interval was 3.6 to $5.0 \%$. The method is compared once a year with the National Glycoprotein Standardization Program (NGSP) to establish the relation to the Diabetes Control and Complications Trial (DCCT) concentrations [26]. To exclude an effect of sample storage at $-20^{\circ}$ C, 99 random samples were also assessed with a more specific, immunological assay, Tinaquant-HbA $\mathrm{Hc}_{\mathrm{c}}$ (Roche Diagnostics, Penzberg, Germany), obtaining high correlation between the two assays $\left(r^{2}=0.98\right.$, linear regression $)$. Hence, $\mathrm{HbA}_{1 \mathrm{c}}$ values were reproducible after storage.

Statistics. Nonparametric Kruskal Wallis and Mann Whitney tests were used to evaluate differences between groups, whereas Wilcoxon Signed Rank test evaluated paired differences. Poisson distribution was applied for calculation of exact confidence intervals. Fishers' exact test evaluated frequency differences. Two-factors-anova and logistic regression, with and without interaction term, were used to compare differences between antibody positive compared with antibody negative and between clinical classifications. A $p$ value of less than 0.05 was considered statistically significant, except in the twofactors anova and logistic regression tests, in which a $p$ value less than 0.01 was selected due to multiple comparisons. Data are shown as median (inter quartile range), unless otherwise stated. 
Table 1. Islet antibody frequencies [absolute numbers (percentages)] and concentrations and number of antibodies [median (interquartile range)] at diagnosis amongst 15 to 34 year-old patients

\begin{tabular}{|c|c|c|c|c|}
\hline & \multicolumn{4}{|c|}{ Type of diabetes } \\
\hline & Type 1 & Type 2 & Unclassifiable & Total \\
\hline Blood sample available & $266(93 \%)$ & $78(96 \%)$ & $47(96 \%)$ & $391(94 \%)$ \\
\hline ICA positive & $143(54 \%)$ & $12(15 \%)$ & $16(34 \%)$ & $171(44 \%)$ \\
\hline JDF units $(\mathrm{ICA}+)$ & $45(80)$ & $68(78)$ & $45(48)$ & $45(80)$ \\
\hline IA-2A positive & $123(46 \%)$ & $12(15 \%)$ & $14(30 \%)$ & $149(38 \%)$ \\
\hline Index (IA-2A+) & $91(90)$ & $94(101)$ & $57(113)$ & $88(90)$ \\
\hline Any antibody positive & $220(83 \%)$ & $18(23 \%)$ & $24(51 \%)$ & $262(67 \%)$ \\
\hline All 3 antibodies & $89(40 \%)$ & $7(39 \%)$ & $10(42 \%)$ & $106(40 \%)$ \\
\hline 2 antibodies & $74(34 \%)$ & $8(44 \%)$ & $7(29 \%)$ & $89(34 \%)$ \\
\hline ICA and GADA & $47(21 \%)$ & $3(17 \%)$ & $4(17 \%)$ & $54(21 \%)$ \\
\hline GADA & $49(22 \%)$ & $3(17 \%)$ & $6(25 \%)$ & $58(22 \%)$ \\
\hline IA-2A & $7(3 \%)$ & $0(0 \%)$ & $1(4 \%)$ & $8(3 \%)$ \\
\hline No. of antibodies & $2(2)$ & $2(1)$ & $2(2)$ & $2(2)$ \\
\hline No antibody & $46(17 \%)$ & $60(77 \%)$ & $23(49 \%)$ & $129(33 \%)$ \\
\hline
\end{tabular}

There were no differences in the number or concentrations of antibodies between antibody positive patients (ab+) in the different groups

\section{Results}

Islet antibodies and clinical classification. The frequencies of ICA, GADA, and IA-2A at diagnosis in relation to the clinical classification provided by the reporting physician are shown in Table 1 . Islet antibodies were found in 262 of $391(67 \%)$ patients; detected in most patients clinically classified as having Type 1 diabetes (220 of 266, 83\%) but also in 18 of 78 (23\%) classified as having Type 2 and in 24 of 47 patients $(51 \%)$ with unclassifiable diabetes. Among antibody positive patients $(a b+)$, there were no differences in the frequency or levels of antibodies with regard to the clinical classification (Table 1). Therfore, two or three antibodies were as prevalent and antibody concentrations were as high in ab+ patients considered to have Type 2 and unclassifiable diabetes as in those $a b+$ patients considered as having Type 1 diabetes.

Clinical features. There were more men among ab+ patients [151 of $262(58 \%)]$ and ab- patients (85 of 129 [66\%]), but the frequency of ab+ did not differ significantly between males and females (151 of 236 [64\%] vs. 111 of 155 [72\%], $p=0.12$ ). GADA were, however, more common in females than in males (107 of 155 [ $69 \%$ ] vs. 136 of 236 [58\%], $p=0.03$ ).

Table 2 shows that patients considered as having Type 1 diabetes were younger, had lower BMI, more severe symptoms, and higher diagnostic blood glucose and $\mathrm{HbA}_{1 \mathrm{c}}$ values, compared with other patients. With or without islet antibodies, patients considered as having Type 1 diabetes had a different phenotype from that shown in those considered as having Type 2 diabetes. In addition, irrespective of clinical classification, BMI and the frequency of obesity $(\mathrm{BMI} \geq 30$ ) differed between $a b+$ patients and $a b-$ patients $(p<0.0001)$. Obesity was uncommon in ab+ patients compared with in ab- patients [18 of $257(7 \%)$ vs. 60 of $125(48 \%), p<0.0001]$. Nevertheless, 18 of 78 $(23 \%)$ obese patients were ab+ (8 of 18 were considered to have Type 1 diabetes), obesity did not exclude $a b+$. Patients with unclassifiable diabetes seemed to have a less advanced form of diabetes suggested by fewer symptoms, shorter duration of symptoms, and relatively low $\mathrm{HbA}_{1 \mathrm{c}}$ values; however, half were $\mathrm{ab}+$ and therefore most likely had Type 1 diabetes.

Beta-cell function. Comparisons between P-C-peptide concentrations at and after diagnosis were carried out in patients tested for C-peptide within 1 week after diagnosis. Among these patients, 30 out of 123 (24\%) $\mathrm{ab}+$ patients had undetectable random P-C-peptide concentrations $(<0.10 \mathrm{nmol} / \mathrm{l})$ at diagnosis compared with only 1 out of $36(3 \%)$ ab- patients $(p=0.003)$. Indeed, 72 out of $123(59 \%)$ ab+ patients had low random P-C-peptide concentrations $(<0.25 \mathrm{nmol} / \mathrm{l}) \mathrm{com}-$ pared with just 2 out of $36(6 \%)$ ab- patients. Nevertheless, 19 out of $30 \mathrm{ab}+$ patients and only $1 \mathrm{ab}-$ patient with undetectable random $\mathrm{P}-\mathrm{C}$-peptide concentrations at diagnosis had retained detectable $\mathrm{C}$-peptide 
Table 2. Characteristics in islet antibody positive $(a b+)$ and negative (ab-) patients clinically classified as Type 1 or Type 2 diabetes or unclassifiable diabetes. Data as median (IQ) or number (frequency)

\begin{tabular}{|c|c|c|c|c|c|c|}
\hline \multirow[t]{2}{*}{ Characteristic } & \multicolumn{3}{|c|}{ ICA, GADA and/or IA-2A positive (ab+) } & \multicolumn{3}{|c|}{ Islet antibody negative (ab-) } \\
\hline & Type 1 & Type 2 & Unclassifiable & Type 1 & Type II & Unclassifiable \\
\hline BMI $\left(\mathrm{kg} / \mathrm{m}^{2}\right)^{\mathrm{a}, \mathrm{b}}$ & $21.8(3.9)$ & $28.7(12.4)$ & $22.9(4.4)$ & $23.7(7.5)$ & $33.8(8.5)$ & $29.4(9.2)$ \\
\hline $\mathrm{BMI} \geq 30 \mathrm{~kg} / \mathrm{m}^{2 \mathrm{a}, \mathrm{b}}$ & $8 / 216(4 \%)$ & $8 / 17(47 \%)$ & $2 / 24(8 \%)$ & $9 / 45(20 \%)$ & $44 / 60(73 \%)$ & $7 / 20(35 \%)$ \\
\hline Insulin (n) (diagnosis) ${ }^{\mathrm{a}}$ & $211 / 220(96 \%)$ & $8 / 18(44 \%)$ & $14 / 24(58 \%)$ & $43 / 46(93 \%)$ & $21 / 60(35 \%)$ & $10 / 22(45 \%)$ \\
\hline Diagnostic B-glucose $(\mathrm{mmol} / \mathrm{l})^{\mathrm{a}}$ & $22.2(8.3)$ & $17.7(8.6)$ & $18.5(4.3)$ & $19.7(8)$ & $17.6(6.7)$ & $15.3(7.8)$ \\
\hline $\mathrm{HbA}_{1 \mathrm{c}}(\%)(\text { diagnosis })^{\mathrm{a}}$ & $8.5(3.8)$ & $8.2(4.5)$ & $7.3(2.9)$ & $8.7(5.3)$ & $8.4(3.9)$ & $7.2(4.4)$ \\
\hline $\mathrm{HbA}_{1 \mathrm{c}}(\%)$ (follow-up) ${ }^{\mathrm{a}}$ & $5.0(1.7)$ & $6.1(1.9)$ & $4.8(1.0)$ & $4.9(1.9)$ & $5.4(2.0)$ & $4.6(0.6)$ \\
\hline$>2$ symptoms $^{\mathrm{c}}$ reported at diagnosis ${ }^{\mathrm{a}}$ & $121 / 218(56 \%)$ & $4 / 18(22 \%)$ & $6 / 24(25 \%)$ & $23 / 46(50 \%)$ & $13 / 60(22 \%)$ & $5 / 23(22 \%)$ \\
\hline Duration of symptoms $s^{c} \geq 3$ months $^{\mathrm{a}}$ & $39 / 214(18 \%)$ & $9 / 14(64 \%)$ & $4 / 20(20 \%)$ & $13 / 39(33 \%)$ & $21 / 50(42 \%)$ & $4 / 18(22 \%)$ \\
\hline
\end{tabular}

Logistic regression and two-factors anova with and without interaction term $(p<0.01$ was considered significant $)$ showed that, with or without islet antibodies, patients considered having Type 1 diabetes had a phenotype different from those considered having Type 2 diabetes

concentrations at follow-up. In contrast, 13 out of 123 $(11 \%) \mathrm{ab}+$ patients and 3 out of $36(8 \%) \mathrm{ab}-$ patients developed undetectable fasting P-C-peptide concentrations after diagnosis. Among all ab- patients included in the follow-up, 13 out of $93(14 \%)$ had low fasting P-C-peptide concentrations $(<0.25 \mathrm{nmol} / \mathrm{l}) ; 12$ out of $13(92 \%)$ had clinical Type 1 diabetes. Around one third (12 of 33, 36\%) of ab- patients with clinical Type 1 diabetes had low fasting P-C-peptide concentrations at follow-up.

The overlap in individual fasting P-C-peptide concentrations between $\mathrm{ab}+$ patients and $\mathrm{ab}-$ patients was large, with $\mathrm{ab}+$ patients having $\mathrm{P}-\mathrm{C}$-peptide concentrations up to $1.6 \mathrm{nmol} / \mathrm{l}$ and $\mathrm{ab}$ - having $\mathrm{P}-\mathrm{C}$-peptide concentrations down to less than $0.10 \mathrm{nmol} / \mathrm{l}$. In patients with clinical Type 2 diabetes, however, fasting $\mathrm{P}$-C-peptide at follow-up differentiated ab+ patients from $a b-$ patients [14/16 (88\%) with fasting P-C-peptide concentrations of $0.52 \mathrm{nmol} / \mathrm{l}$ or less were $\mathrm{ab}+\mathrm{vs}$. only $2 / 41(5 \%)$ with fasting P-C-peptide concentrations above $0.52 \mathrm{nmol} / \mathrm{l}, p<0.0001$ ] (Fig. 1).

Among patients GADA-positive at diagnosis with clinical Type 2 or unclassifiable diabetes, those with IA-2A and/or ICA $(n=23)$ had lower fasting P-C-peptide concentrations than those without $(\mathrm{n}=7)[0.22$ $(0.27) \mathrm{nmol} / \mathrm{l}$ vs. $0.76(0.39) \mathrm{nmol} / \mathrm{l}, p=0.001]$.

Islet antibodies developing de novo after diagnosis. Among ab- patients at diagnosis, 8 out of 93 (9\%) developed islet antibodies $(1 \mathrm{ab}+)$ after diagnosis, four with clinical Type 1 (2 developed ICA+ and 2 GADA+) and four with clinical Type 2 diabetes (two developed ICA+, one GADA+, and one IA-2A+). Among the eight patients with only IA-2A+ at diagnosis, one had developed GADA+ and three ICA+. All $\mathrm{a}=$ analyses considering clinical classification: $p<0.0001$ in all comparisons except $\mathrm{HbA}_{1 \mathrm{c}}$ (diagnosis) $p=0.0005, \mathrm{HbA}_{1 \mathrm{c}}$ (follow-up) $p=0.008$, and Duration of symptoms $\geq 3$ months $p=0.006, \mathrm{~b}$ analyses considering ab+ vs. ab-: $p<0.0001$, $\mathrm{c}=$ polyuria, weight loss, fatigue, and/or coma

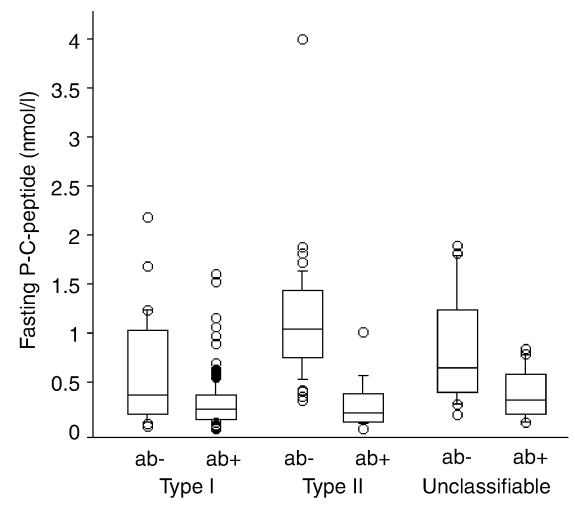

Fig. 1. Fasting P-C-peptide concentrations at follow-up in islet antibody positive $(\mathrm{ab}+)$ and negative $(\mathrm{ab}-)$ patients with different clinical classifications. Horizontal lines indicate $10^{\text {th }}, 25^{\text {th }}$, $50^{\text {th }}, 75^{\text {th }}$, and $90^{\text {th }}$ centiles, respectively. Among patients with clinical Type 2 diabetes, fasting P-C-peptide concentrations at follow-up differentiated $a b+$ from $a b-$

but one (seven of eight) with only IA-2A+ at diagnosis were considered to have clinical Type 1 diabetes.

Fig. 2 shows that $a b-$ patients developing antibody positivity after diagnosis and in patients with only IA-2A+ at diagnosis developing GADA+ or ICA+ after diagnosis, fasting P-C-peptide concentrations at follow-up were lower compared with continuously ab- patients ( $p=0.04$ and $p=0.006$, respectively). Therefore, ab- patients who became $a b+$, as well as patients with only IA-2A+ who developed other antibodies after diagnosis, showed impaired beta-cell function at follow-up.

Objective classification of diabetes. Figure 3 shows that $76 \%(95 \%$ CI $71-81 \%, 239$ of 313$)$ of the patients followed up had "objective" Type 1 diabetes 


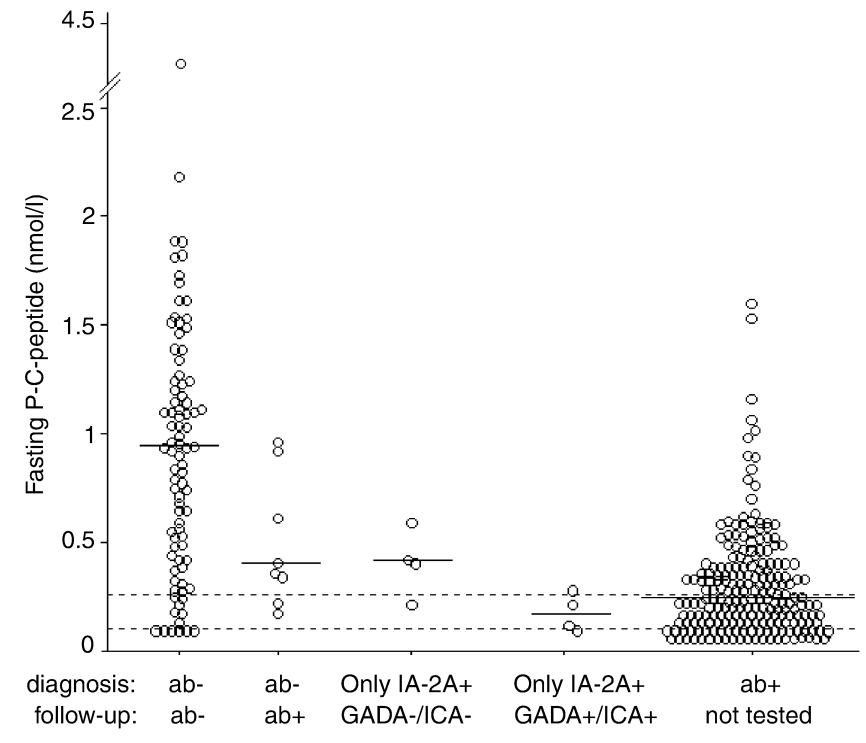

Fig. 2. Fasting P-C-peptide concentrations at follow-up. Horizontal lines indicate median. Dotted horizontal lines indicate detection limit $(0.10 \mathrm{nmol} / \mathrm{l})$ and lower reference value $(0.25 \mathrm{nmol} / \mathrm{l})$, respectively. Antibody negative $(\mathrm{ab}-)$ who had become $\mathrm{ab}+$ at follow-up had lower fasting P-C-peptide concentrations than constant $\mathrm{ab}-(p=0.04)$ and higher than patients $\mathrm{ab}+$ at diagnosis of diabetes $(p=0.02)$. Patients only IA-2A+ at diagnosis who had become GADA+ or ICA+ $(n=4)$ had lower fasting P-C-peptide concentrations than constant $\mathrm{ab}-$ $(p=0.006)$

Fig. 3. Objective classification of diabetes based on islet antibodies $(\mathrm{ab}+)$ and/or fasting plasma C-peptide concentration (normal range $0.25-0.75 \mathrm{nmol} / \mathrm{l}$ ) in relation to the clinical classification in 31315 to 34 year-old diabetic patients. Most (74 of $85,87 \%$ ) antibody negative patients $(\mathrm{ab}-)$ had objective Type 2 diabetes with normal to high fasting C-peptide concentrations at follow-up; however, $11 \mathrm{ab}-$ had low fasting plasma C-peptide concentrations and thus had objective Type 1 diabetes. Insulin treatment $(\mathrm{a} / \mathrm{b} / \mathrm{c} / \mathrm{d} ; \mathrm{a}=\mathrm{at}$ diagnosis and follow-up, $\mathrm{b}=$ only at diagnosis, $\mathrm{c}=$ only at follow-up, and $\mathrm{d}=$ neither at diagnosis or follow-up) was not specific for Type 1 diabetes (ab+ at diagnosis or follow-up or low fasting P-C-peptide) which was closely associated with clinical Type 1 diabetes [i.e. only $9 \%(5-13 \%, 19$ of 218$)$ of those clinically considered to have Type 1 diabetes seemed to have objective Type 2 diabetes]. Among patients with clinical Type 1 diabetes, only 5\% (2-8\%, 10 of 218) had low P-C-peptide concentrations and no islet antibodies. Therefore, being ab+ was the marker most strongly associated with clinical Type 1 diabetes. In contrast, among clinical Type 2 diabetic patients, $31 \%$ $(20-45 \%, 18$ of 58$)$ were most likely wrongly classified, as they had Type 1 diabetes in accordance with being ab+. Patients with unclassifiable diabetes, 59\% $(42-75 \%, 22$ of 37$)$ seemed to have Type 1 diabetes, based on being $\mathrm{ab}+$, and in one case on a low P-Cpeptide concentration. There was an association between insulin treatment and objective Type 1 diabetes (97\%). In contrast, about half of the patients objectively classified as having Type 2 diabetes were on insulin treatment, albeit half of them had a clinical classification of Type 2 diabetes. Patients with clinical Type 2 diabetes not insulin treated at diagnosis, insulin treatment had been initiated at follow-up in 6 out of $7(86 \%) \mathrm{ab}+$ patients compared with only 5 out of $26(19 \%)$ ab - patients $(p=0.003)$. In agreement, insulin treatment had been ended in five patients, all ab-.

\section{Discussion}

Amongst young adult people aged 15 to 34 years with recently diagnosed diabetes, most with clinical Type 1 diabetes $(185$ of $218,85 \%)$ were $a b+$ at diagnosis. In addition, 14 of $58(24 \%)$ with clinical Type 2 and 21 of $37(57 \%)$ with unclassifiable diabetes were $a b+$ at diagnosis. Further to this, 4 out of 33 patients (12\%) who were $a b-$ with clinical Type 1 diabetes and 4 out of $44(9 \%)$ who were ab- with Type 2 diabetes had

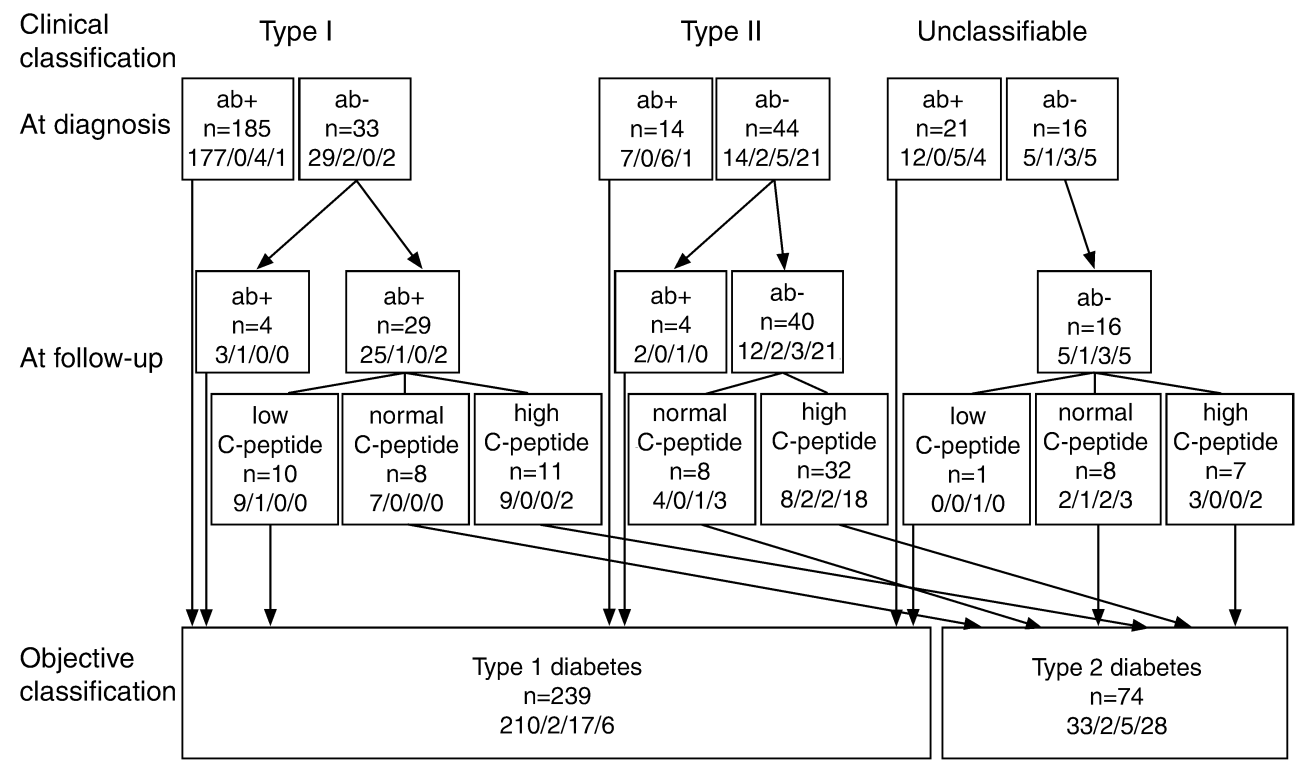


converted to $\mathrm{ab}+$ at follow-up. Based on putative autoimmune aetiology (positive for islet antibodies), 228 out of 313 (73\%) had objective Type 1 diabetes. In addition, 10 out of 29 patients (34\%) who were constantly ab- with clinical Type 1 and 1 out of $16(6 \%)$ with unclassifiable diabetes had fasting P-C-peptide concentrations below the normal range $(<0.25 \mathrm{nmol} / \mathrm{l})$ at follow-up. Accordingly, if beta-cell failure in $a b-p a-$ tients was included, 239 of $313(76 \%)$ had objective Type 1 diabetes.

According to the new ADA and WHO criteria, patients with islet antibodies should be considered as having autoimmune Type 1 diabetes $[12,13]$, as supported by the observation that also patients negative for ICA and IA-2A but GADA+ develop complete beta-cell failure within 12 years after diagnosis of diabetes [27]. Consequently, antibody measurements at diagnosis, as shown in this study, improve the classification of diabetes. Patients who were ab- at diagnosis can, however, not be completely excluded from having autoimmune Type 1 diabetes. Patients who were $a b-$ before and at the diagnosis of obvious Type 1 diabetes have Type 1 diabetic HLA risk-alleles [28]. In agreement, among ab- patients considered as having Type 1 diabetes C-peptide concentrations are lower in patients with Type 1 diabetic HLA risk-alleles compared with those without [29]. Albeit HLA genotyping has not yet been conducted, the low or undetectable fasting P-C-peptide concentrations observed in 36\% of $a b-$ patients clinically classified as having Type 1 diabetes in this study suggest that the clinical classification was correct in these patients. In fact, ab- patients could have antibodies against other antigens not tested for [30], low antibody concentrations could have been missed in our assays, or measurable antibody concentrations might not develop until after diagnosis [31, 32] and, indeed, confirmed in this study. In this context it was interesting that de novo development of GADA or ICA occurred both in IA-2A- and IA-2A+. Hence, both GAD65 and the IA-2 protein may be involved in the primary Type 1 diabetic process. Our study therefore confirms that in adults, as in children [33, 34], there is no single dominating pattern in the development of the different antibodies. A second follow-up sample collected 4 years after diagnosis will clarify the further course of antibody development. Nevertheless, although repeated antibody measurements within the first 4 months discovered only a small proportion of ab+ patients ( 8 of 228, 4\%), among young adults patients antibody negative at diagnosis our study underlines the importance of antibody measurements not only at but also after diagnosis of diabetes.

According to the WHO and ADA guidelines, patients with Type 1 diabetes without evidence of autoimmunity, like the $11 \mathrm{ab}$ - patients with low fasting P-C-peptide concentrations in the current study, are classified as having idiopathic Type 1 diabetes [12,
13]. Our $11 \mathrm{ab}-$ patients did not, however, differ in any aspect from $\mathrm{ab}+$ patients with low fasting P-Cpeptide concentrations at follow-up. Thus, they do not fit with the description of the rapid-onset ab- Type 1 diabetes reported in Japanese patients [35] not yet confirmed in Caucasians [36, 37]. Idiopathic Type 1 diabetes is described mostly among individuals of African or Asian origin [38]; most of our ab- patients with low P-C-peptide concentrations were of Swedish origin. We therefore have to conclude that idiopathic Type 1 diabetes could occur in Caucasians.

The question is whether a low P-C-peptide concentration is always a sign of Type 1 diabetes. Low P-Cpeptide concentrations have been observed among patients with Type 2 diabetes after intensive insulin treatment inducing beta-cell rest [39]; however, it seems unlikely that beta-cell rest was induced in any of our patients. Maturity-Onset Diabetes of the Young (MODY), a monogenic form of diabetes with impaired insulin secretion [40,41], has also to be considered in our young adult ab- patients with low P-Cpeptide concentrations. Undetectable P-C-peptide concentrations, as observed in 6 of $11 \mathrm{ab}-$ patients with low fasting P-C-peptide concentrations, are, however, unusual in MODY.

Permanent insulin treatment started within 6 months after diagnosis of diabetes [42] as well as immediate and permanent insulin treatment in patients under 30 years of age has previously been shown to be closely associated with Type 1 diabetes [43]. Here we show that early insulin treatment is strongly associated with but not specific for Type 1 diabetes. In fact, in this study, 12 out of $40(30 \%)$ ab- patients with high fasting C-peptide concentrations $(>0.75 \mathrm{nmol} / \mathrm{l})$ were treated with insulin both at and after diagnosis. Accordingly, insulin treatment has to be combined with low C-peptide concentrations to be used as a criterion for Type 1 diabetes.

Compared with DISS during the years 1992 to 1993 [44], in the DISS study of 1998, ab- patients were only half as often clinically classified as having Type 1 diabetes. Since the total frequency of ab- patients among incident cases remained unchanged, it seems that the clinical classification apparently has improved. Most likely, the clinicians' awareness of Type 2 diabetes in young adults has increased in Sweden from 1992 to 1993 until 1998. According to the new ADA and WHO criteria, most patients with Type 2 diabetes should be obese. In agreement, amongst our patients, almost half of the $a b-$ patients were obese (BMI $\geq 30)$ compared with only $7 \%$ of the $\mathrm{ab}+$ patients. Nevertheless, we confirm that obesity does not exclude Type 1 diabetes [45, 46]. In our study, as many as $23 \%$ of obese patients were ab+, therefore obesity is not a specific sign of Type 2 diabetes.

In contrast to DISS from 1992 to 1993 [44], in this study there were no associations between the clinical classifications and the number or concentrations of 
antibodies. The reason for the discrepancy is unclear, but it could be due to that the antibodies were detected by microsepharose conjugated with monoclonal antibodies specific for human immunoglobulin light chains whereas we used Protein A Sepharose, an Fc receptor [47]. Amongst GADA positive patients with clinical Type 2 or Unclassifiable diabetes, those with IA-2A+ and/or ICA+ had lower fasting P-C-peptide concentrations at follow-up than those without. We confirm that $\mathrm{C}$-peptide concentrations during the first years after diagnosis are lower in patients with multiple antibodies compared with in those with only GADA+, as observed in adult diabetic patients [27]. A follow-up of the DISS 1992 to 1993 cohort after 4 years showed that, among patients with only ICA+, or IA-2A+, or both, the P-C-peptide concentrations decreased later compared with GADA+ [48], indicating that GADA- patients with ICA+, IA-2A+ or both had a less aggressive form of Type 1 diabetes (GADA-) [49]. We can not confirm this difference among patients $a b+$ at diagnosis. As most of our $a b+$ patients $(93 \%)$ were GADA+, our study suggests that this slow and less aggressive form of Type 1 diabetes was not common during the year when the current study was conducted. Indeed, our study infers that this form of diabetes has a secular and temporal variation. Future studies in DISS will show whether this hypothesis is true. In this context it could be mentioned that the frequency of GADA was higher $(p=0.03)$ in female patients $(69 \%)$ than in male patients $(58 \%)$. The frequency in our female patients corresponded well to that $(69 \%)$ in Finnish women aged 20 to 39 years with recently diagnosed diabetes [50].

$\mathrm{HbA}_{1 \mathrm{c}}$ values among patients with unclassifiable diabetes were lower than in patients classified as having Type 1 or Type 2 diabetes. This suggests that, despite half of them being ab+, patients with unclassifiable diabetes had a mild form of diabetes. As Unclassifiable patients had as high antibody concentrations and number of different antibodies as other ab+ patients, our observation indicates that there might be other forms of slowly progressive Type 1 diabetes than that previously described [49].

In some $a b+$ patients, beta-cell function is preserved for many years after diagnosis [51]. Such slow progressive Type 1 diabetes generally occurs in adult patients and is sometimes referred to as latent autoimmune diabetes in adults (LADA) [52] as mentioned in the WHO report [13]. The LADA definition is often restricted to ab+ adult patients with clinical Type 2 diabetes at diagnosis and without insulin treatment for at least 3 to 6 months after diagnosis [53]. In our opinion, the LADA criteria are difficult to define and ambiguous to use in clinical practice. For instance, LADA does not include insulin treated clinical Type 1 diabetic patients with slow-onset (preserved beta-cell function at diagnosis) who, according to this study, could constitute as much as one third of young adult diabetic patients (104 of 313,33\%). We suggest that patients should be primarily defined as $a b+$ or $a b-$, and to that beta-cell function based on C-peptide measurements should be added. The importance of detecting $a b+$ patients with preserved beta-cell function could be paramount in the future. Observations that heat-shock protein peptide (DiaPep277) [54] and a nonactivating humanized monoclonal antibody against CD3 [55] might halt or arrest progressive beta-cell dysfunction indicate that it will be of major importance to identify patients with slow progressive Type 1 diabetes. We suggest $a b+$ patients with normal C-peptide concentrations as a target group for intervention trials.

In conclusion, among 15 to 34 year old newly diagnosed patients, the classification of diabetes is improved if islet antibody measurements are carried out. In addition, $a$ few $a b-$ patients convert after diagnosis to being $a b+$. Whereas most $a b-$ patients have Type 2 diabetes, those with low fasting P-C-peptide concentrations might have idiopathic Type 1 diabetes of nonautoimmune or autoimmune origin. Most patients with clinical Type 1 diabetes $(91 \%)$ had objective Type 1 diabetes, i.e. they were $a b+$ at diagnosis or follow-up and/or low fasting P-C-peptide concentrations at follow-up. In contrast, almost one third with clinical Type 2 diabetes, and more than half with unclassifiable diabetes had objective Type 1 diabetes. Our observation that half of ab+ young adult diabetic patients had preserved beta-cell function argues for the need for therapeutical interventions to preserve beta-cell function.

Acknowledgements. We thank Drs J. Östman, founder of DISS, and G. Blohmé, former chairman of DISS, for their major contributions to DISS over the years and for helpful comments in preparing this paper. We thank Dr B. Vogt for providing the Tinaquant- $\mathrm{HbA}_{1 \mathrm{c}}$ assay as well as Dr P. Fernlund for C-peptide measurements. U. Gustavsson, I. Larsson, A. Radelius, and C. Rosborn are thanked for excellent technical assistance, and J.-Å. Nilsson, Department of Statistics and Information Processing, Malmö University Hospital, is thanked for expert statistical assistance. Grants from the Juvenile Diabetes Foundation-Wallenberg Diabetes Research Program (K98-99JD-128B), Lundström Foundation, Novo-Nordic Foundation, Research founds at Malmö University Hospital and the Faculty of Medicine at Lund University, Albert Påhlsson Foundation, and the Swedish Diabetes Association supported this study.

\section{References}

1. Gottsäter A, Ahmed M, Lilja B, Fernlund P, Sundkvist G (1996) Islet cell antibodies at diagnosis, but not leanness, relate to a better cardiovascular risk factor profile 5 years after diagnosis of NIDDM. Diabetes Care 19:60-63

2. Isomaa B, Almgren P, Henricsson M et al. (1999) Chronic complications in patients with slowly progressing autoimmune type 1 diabetes (LADA). Diabetes Care 22:1347-1353

3. Lohmann T, Kellner K, Verlohren HJ et al. (2001) Titre and combination of ICA and autoantibodies to glutamic acid 
decarboxylase discriminate two clinically distinct types of latent autoimmune diabetes in adults (LADA). Diabetologia 44:1005-1010

4. National Diabetes Data Group (1979) Classification and diagnosis of diabetes mellitus and other categories of glucose intolerance. Diabetes 28:1039-1057

5. World Health Organization (1980) WHO Expert Committee on Diabetes Mellitus: second report. WHO Technical Report Series No 646, World Health Organisation, Geneva

6. World Health Organization (1985) Diabetes mellitus. Report of a WHO Study Group. WHO Technical Report Series No 727, World Health Organisation, Geneva

7. Irvine WJ, McCallum CJ, Gray RS et al. (1977) Pancreatic islet-cell antibodies in diabetes mellitus correlated with the duration and type of diabetes, coexistent autoimmune disease, and HLA type. Diabetes 26:138-147

8. Groop LC, Bottazzo GF, Doniach D (1986) Islet cell antibodies identify latent type I diabetes in patients aged 35-75 years at diagnosis. Diabetes 35:237-241

9. Hagopian WA, Karlsen AE, Gottsäter A et al. (1993) Quantitative assay using recombinant human islet glutamic acid decarboxylase (GAD65) shows that $64 \mathrm{~K}$ autoantibody positivity at onset predicts diabetes type. J Clin Invest 91:368-374

10. Abourizk NN, Dunn JC (1990) Types of diabetes according to National Diabetes. Data Group Classification. Limited applicability and need to revisit. Diabetes Care 13:11201123

11. Arnqvist HJ, Littorin B, Nyström L et al. (1993) Difficulties in classifying diabetes at presentation in the young adult. Diabet Med 10:606-613

12. American Diabetes Association (1997) Report of the Expert Committee on the diagnosis and classification of diabetes mellitus. Diabetes Care 20:1183-1197

13. Alberti KG, Zimmet PZ (1998) Definition, diagnosis and classification of diabetes mellitus and its complications. Part 1: diagnosis and classification of diabetes mellitus provisional report of a WHO Consultation. Diabet Med 15:539-553

14. Östman J, Arnqvist H, Blohmé G et al. (1986) Epidemiology of diabetes mellitus in Sweden. Results of the first year of a prospective study in the population age group 15-34 years. Acta Med Scand 220:437-445

15. Turner R, Stratton I, Horton V et al. (1997) UKPDS 25: autoantibodies to islet-cell cytoplasm and glutamic acid decarboxylase for prediction of insulin requirement in type 2 diabetes. Lancet 350:1288-1293

16. Wroblewski $\mathrm{M}$, Gottsäter $\mathrm{A}$, Lindgärde $\mathrm{F}$, Fernlund $\mathrm{P}$, Sundkvist G (1998) Gender, autoantibodies, and obesity in newly diagnosed diabetic patients aged $40-75$ years. Diabetes Care 21:250-255

17. Landin-Olsson M, Karlsson FA, Lernmark A, Sundkvist G (1992) Islet cell and thyrogastric antibodies in 633 consecutive 15 - to $34-y r-o l d$ patients in the diabetes incidence study in Sweden. Diabetes 41:1022-1027

18. Törn C, Landin-Olsson M, Östman J et al. (2000) Glutamic acid decarboxylase antibodies (GADA) is the most important factor for prediction of insulin therapy within 3 years in young adult diabetic patients not classified as Type 1 diabetes on clinical grounds. Diabetes Metab Res Rev $16: 442-447$

19. Littorin B, Sundkvist G, Hagopian W et al. (1999) Islet cell and glutamic acid decarboxylase antibodies present at diagnosis of diabetes predict the need for insulin treatment. A cohort study in young adults whose disease was initially labeled as type 2 or unclassifiable diabetes. Diabetes Care 22:409-412
20. Borg H, Fernlund P, Sundkvist G (1997) Measurements of antibodies to glutamic acid decarboxylase 65 (GADA): two new125I assays compared with [35S]GAD 65-ligand binding assay. Clin Chem 43:779-785

21. Borg H, Fernlund P, Sundkvist G (1997) Protein tyrosine phosphatase-like protein IA2-antibodies plus glutamic acid decarboxylase 65 antibodies (GADA) indicates autoimmunity as frequently as islet cell antibodies assay in children with recently diagnosed diabetes mellitus. Clin Chem 43:2358-2363

22. Borg H, Gottsäter A, Landin-Olsson M, Fernlund $\mathrm{P}$, Sundkvist G (2001) High levels of antigen-specific islet antibodies predict future beta- cell failure in patients with onset of diabetes in adult age. J Clin Endocrinol Metab 86: 3032-3038

23. Gottsäter A, Landin-Olsson M, Fernlund P, Gullberg B, Lernmark Å, Sundkvist G (1992) Pancreatic beta-cell function evaluated by intravenous glucose and glucagon stimulation. A comparison between insulin and C-peptide to measure insulin secretion. Scand J Clin Lab Invest 52: 631-639

24. Jeppsson JO, Jerntorp P, Almer LO, Persson R, Ekberg G, Sundkvist G (1996) Capillary blood on filter paper for determination of $\mathrm{HbA} 1 \mathrm{c}$ by ion exchange chromatography. Diabetes Care 19:142-145

25. Jeppsson JO, Jerntorp P, Sundkvist G, Englund H, Nylund V (1986) Measurement of hemoglobin A1c by a new liquidchromatographic assay: methodology, clinical utility, and relation to glucose tolerance evaluated. Clin Chem 32: 1867-1872

26. Little RR, Rohlfing CL, Wiedmeyer HM, Myers GL, Sacks DB, Goldstein DE (2001) The national glycohemoglobin standardization program: a five-year progress report. Clin Chem 47:1985-1992

27. Borg H, Gottsäter A, Fernlund P, Sundkvist G (2002) A 12-year prospective study of the relationship between islet antibodies and beta-cell function at and after the diagnosis in patients with adult-onset diabetes. Diabetes 51:1754-1762

28. Pietropaolo M, Becker DJ, LaPorte RE et al. (2002) Progression to insulin-requiring diabetes in seronegative prediabetic subjects: the role of two HLA-DQ high-risk haplotypes. Diabetologia 45:66-76

29. Weets I, Siraux V, Daubresse JC et al. (2002) Relation between disease phenotype and HLA-DQ genotype in diabetic patients diagnosed in early adulthood. J Clin Endocrinol Metab 87:2597-2605

30. Aanstoot H-J, Kang S-M, Kim J et al. (1996) Identification and characterization of Glima 38, a glycosylated islet cell membrane antigen, which together with GAD65 and IA2 marks the early phases of autoimmune response in Type 1 diabetes. J Clin Invest 97:2772-2783

31. Landin-Olsson M, Arnqvist HJ, Blohmé G et al. (1999) Appearance of islet cell autoantibodies after clinical diagnosis of diabetes mellitus. Autoimmunity 29:57-63

32. Decochez K, Tits J, Coolens JL et al. (2000) High frequency of persisting or increasing islet-specific autoantibody levels after diagnosis of type 1 diabetes presenting before 40 years of age. The Belgian Diabetes Registry. Diabetes Care 23:838-844

33. Kimpimäki T, Kulmala P, Savola K et al. (2000) Diseaseassociated autoantibodies as surrogate markers of type 1 diabetes in young children at increased genetic risk. Childhood Diabetes in Finland Study Group. J Clin Endocrinol Metab 85:1126-1132

34. Kupila A, Keskinen P, Simell T et al. (2002) Genetic risk determines the emergence of diabetes-associated autoantibodies in young children. Diabetes 51:646-651 
35. Imagawa A, Hanafusa T, Miyagawa J, Matsuzawa Y (2000) A novel subtype of type 1 diabetes mellitus characterized by a rapid onset and an absence of diabetes-related antibodies. Osaka IDDM Study Group. N Engl J Med 342:301-307

36. Tiberti C, Buzzetti R, Anastasi E et al. (2000) Autoantibody negative new onset type 1 diabetic patients lacking high risk HLA alleles in a Caucasian population: are these type $1 \mathrm{~b}$ diabetes cases? Diabetes Metab Res Rev 16:8-14

37. Carreras G, Mauricio D, Perez A, de Leiva A (2000) Can all newly diagnosed subjects without type 1 diabetes-associated autoimmune markers be classified as type $1 \mathrm{~b}$ diabetic patients? Diabetes Care 23:1715-1716

38. Pinero-Pilona A, Raskin P (2001) Idiopathic type 1 diabetes. J Diabetes Complications 15:328-335

39. Murayama Y, Kawai K, Watanabe Y, Yoshikawa $H$, Yamashita K (1989) Insulin and glucagon secretion are suppressed equally during both hyper- and euglycemia by moderate hyperinsulinemia in patients with diabetes mellitus. J Clin Endocrinol Metab 68:925-931

40. Lehto M, Tuomi T, Mahtani MM et al. (1997) Characterization of the MODY3 phenotype. Early-onset diabetes caused by an insulin secretion defect. J Clin Invest 99:582-591

41. Hattersley AT (1998) Maturity-onset diabetes of the young: clinical heterogeneity explained by genetic heterogeneity. Diabet Med 15:15-24

42. Douek IF, Gillespie KM, Bingley PJ, Gale EA (2002) Diabetes in the parents of children with type I diabetes. Diabetologia 45:495-501

43. Green A, Hougaard P (1983) Epidemiological studies of diabetes mellitus in Denmark: 4. Clinical characteristics of insulin-treated diabetes. Diabetologia 25:231-234

44. Schranz DB, Bekris L, Landin-Olsson M et al. (2000) Newly diagnosed latent autoimmune diabetes in adults (LADA) is associated with low level glutamate decarboxylase (GAD65) and IA-2 autoantibodies. Diabetes Incidence Study in Sweden (DISS). Horm Metab Res 32:133-138

45. Gottsäter A, Landin-Olsson M, Lernmark A, Fernlund P, Sundkvist G (1994) Islet cell antibodies are associated with beta-cell failure also in obese adult onset diabetic patients. Acta Diabetol 31:226-231
46. Juneja R, Hirsch IB, Naik RG, Brooks-Worrell BM, Greenbaum CJ, Palmer JP (2001) Islet cell antibodies and glutamic acid decarboxylase antibodies, but not the clinical phenotype, help to identify type $1(1 / 2)$ diabetes in patients presenting with type 2 diabetes. Metabolism 50:1008-1013

47. Tashiro M, Montelione GT (1995) Structures of bacterial immunoglobulin-binding domains and their complexes with immunoglobulins. Curr Opin Struct Biol 5:471-481

48. Törn C, Landin-Olsson M, Lernmark Å et al. (2001) Combinations of beta cell specific autoantibodies at diagnosis of diabetes in young adults reflects different courses of beta cell damage. Autoimmunity 33:115-120

49. Seissler J, de Sonnaville J, Morgenthaler N et al. (1998) Immunological heterogeneity in type I diabetes: presence of distinct autoantibody patterns in patients with acute onset and slowly progressive disease. Diabetologia 41:891897

50. Tuomilehto J, Zimmet P, Mackay IR et al. (1994) Antibodies to glutamic acid decarboxylase as predictors of insulindependent diabetes mellitus before clinical onset of disease. Lancet 343:1383-1385

51. Takeda H, Kawasaki E, Shimizu I et al. (2002) Clinical, autoimmune, and genetic characteristics of adult-onset diabetic patients with GAD autoantibodies in Japan (Ehime Study). Diabetes Care 25:995-1001

52. Tuomi T, Groop L, Zimmet PZ, Rowley MJ, Knowles W, Mackay IR (1993) Antibodies to glutamic acid decarboxylase reveal latent autoimmune diabetes mellitus in adults with a non-insulin-dependent onset of disease. Diabetes 42:359-362

53. Tuomi T, Carlsson A, Li H et al. (1999) Clinical and genetic characteristics of type 2 diabetes with and without GAD antibodies. Diabetes 48:150-157

54. Raz I, Elias D, Avron A, Tamir M, Metzger M, Cohen IR (2001) Beta-cell function in new-onset type 1 diabetes and immunomodulation with a heat-shock protein peptide (DiaPep277): a randomised, double-blind, phase II trial. Lancet 358:1749-1753

55. Herold KC, Hagopian W, Auger JA et al. (2002) Anti-CD3 monoclonal antibody in new-onset type 1 diabetes mellitus. N Engl J Med 346:1692-1698 